\title{
Unexpected disproportion observed in species composition between oak mixed stands and their progeny populations
}

\author{
Monika DERING, Andrzej LEWANDOWSKI* \\ Institute of Dendrology, Polish Academy of Sciences, Parkowa 5, 62-035 Kórnik, Poland
}

(Received 27 April 2006; accepted 30 October 2006)

\begin{abstract}
We used morphological analysis to assess species composition of natural regenerations and progeny plantations established from two mixed oak stands in Jamy and Legnica, Poland. Despite equal proportions of pedunculate (Quercus robur) and sessile oak (Quercus petrea) in seed stands, the species composition differed strikingly. In all progeny populations, pedunculate oak dominated, reaching $89.5 \%$ and $96.6 \%$ in Legnica and Jamy, respectively. However, sessile oak predominated in natural regenerations. Morphological studies indicated a varied number of phenotypically intermediate or mosaic individuals. Among artificial populations, the highest number of putative hybrids was observed in Legnica (average $2.5 \%$ ) and the lowest in Jamy (average 0.2\%). Hybrids in natural regeneration were 1\% in Legnica and 8\% in Jamy. The disproportionate species composition could result from either unintentional indirect acorn selection during collection or selection in nursery practice. We discuss the role of ecophysiological differences between species in biased species representation in progeny populations.
\end{abstract}

Q. robur / Q. petrea / mixed stand / progeny plantation / hybridization

Résumé - Disproportion inattendue dans la composition spécifique observée entre des peuplements mélangés de chêne et leurs descendances. Nous avons utilisé des analyses de caractères morphologiques pour déterminer la composition spécifique dans des régénérations naturelles et dans des plantations de chêne, issues de deux peuplements mélangés à Jamy et Legnica, Pologne. Malgré des proportions égales entre chêne pédonculé (Quercus robur) et chêne sessile (Quercus petrea) dans les peuplements semenciers, la composition spécifique y est étonnamment différente. Dans toutes les plantations, le chêne pédonculé domine et atteint des proportions de $89,5 \%$ et $96,6 \%$ à Legnica et Jamy respectivement. Cependant, le chêne sessile prédomine dans les régénérations naturelles. Les analyses morphologiques indiquent un nombre variable d'individus phénotypiquement intermédiaires ou mosaïques. Parmi les peuplements artificiels, le plus grand nombre d'hybrides putatifs est observé à Legnica (en moyenne $2,5 \%$ ) et le plus faible à Jamy $(0,2 \%$ en moyenne). Dans les régénérations naturelles, les hybrides représentent $1 \%$ à Legnica et $8 \%$ à Jamy. Ces différences pourraient résulter soit d'une sélection indirecte involontaire des glands lors de la récolte soit d'une sélection lors de l'élevage en pépinière. Nous discutons aussi du rôle des différences écophysiologiques entre les espèces dans la représentation biaisée des espèces dans les plantations.

Q. robur / Q. petrea / peuplement mélangé / descendance / hybridation

\section{INTRODUCTION}

Pedunculate oak (Quercus robur L.) and sessile oak (Quercus petrea (Matt.) Lieb.) are abundant and important components of European forests. Hence, both species have been the focus of the most intensive studies, especially since the onset in the 1980s of a decline in oak forests $[14,19]$. There are three native Quercus species in Poland: $Q$. pubescens (pubescent oak), Q. robur, and $Q$. petrea, but only the last two species are economically important. Forest coverage in Poland is about $28 \%$. Q. robur and $Q$. petrea represent about $6 \%$ of total forest area; however, they make up $40 \%$ of the forest area in some parts of country [31].

These two oak species are closely related and despite different ecological requirements share a wide sympatric distribution. $Q$. robur is typical for rich, humid sites even with high water tables and frequent flooding. Unlike $Q$. robur, $Q$. petrea prefers drier, less-rich soils. The root system is better devel-

* Corresponding author: alew@ rose.man.poznan.pl oped in sessile oak, making it more drought resistant than pedunculate oak. Differences between the species also exist with respect to light requirements. $Q$. petrea tolerates more dense and shaded sites whereas $Q$. robur needs higher insolation. Despite ecophysiological differences, these two oak species are often mixed, especially if site conditions are a humid and dry mosaic.

Sympatric distribution and mixed stands may contribute to interspecific hybridization between pedunculate and sessile oak. Several observations seem to support this hypothesis. First, many morphologically intermediate forms between pure parental species are commonly recognized [3, 23, 32]. Field observations led to experiments of artificial crosses, which revealed the possibility of intermating, although higher success in crosses was noted with $Q$. petrea as a pollen donor [24].

Methods based on DNA polymorphisms indicate a low level of differentiation between the species [2, 17]. Analysis of oak cpDNA polymorphisms revealed extensive sharing of cpDNA haplotypes among oak species [20]. The specific pattern of haplotype variation reflects geographical differentiation 
and similar postglacial history and suggests interspecific gene flow $[6,21,28]$. Eventually, DNA marker studies failed to identify any true species-specific markers. Moreover, despite consistency at the genetic level, both oak species are morphologically distinguishable, and morphological analysis is still a reliable tool for species identification in this genus $[7,12]$.

It has been recently recognized that the protection of forest genetic resources, in a broad sense, will be a major task for future forest management. Genetic variability provides adaptation potential for species and is fundamental for their evolution and the survival of individuals. Changing environmental conditions, especially at current rates, may render natural mechanisms of species adaptation insufficient, making conservation of genetic variability a highly important issue. Both Quercus species, together with other main forest-tree species, are the target of "The Programme for the Conservation of Forest Genetic Resources and the Breeding of Forest Tree Species in Poland in the Years 1991-2010" [16]. The strategic goals of the programme are conservation of forest genetic resources, genetic improvement of the seed base, and breeding of forest-tree species. Management efforts targeting protection of forest-tree species gene pools by in situ and ex situ conservation include choosing selected seed stands and establishing progeny plantations, respectively. Selected seed stands are the best species populations chosen in the context of their phenotypic value. Establishing a progeny plantation helps to ensure the continuation of genetic diversity deposited in selected seed stands. There are overall 1419 ha and 590 ha of selected seed stands of $Q$. robur and $Q$. petrea in Poland, respectively [15]. Because forest management practice has resulted in the treatment of the two oak species as one for a long time, many of these seed stands can be of mixed composition. The influence of oak hybridization on seed quality is unknown, but recent State Forests regulations concerning forest reproductive material have recommended converting such two-species stands into one-species stands.

Our objective was to analyze the species composition of progeny plantations established from seeds gained from oak selected seed stands of mixed composition. We were interested in changes in species composition of such mixed oak stands depending on natural or artificial regeneration. The focal point was to elucidate whether or not: (1) the species composition of progeny plantations reflects that of selected seed stands; (2) the species composition in plantations established in different years from the same seed source is also different depending on year of establishing. We also wanted to compare the progeny plantations and maternal stands with their natural regeneration to identify any differences in species composition or proportions.

\section{MATERIALS AND METHODS}

The populations studied were progeny plantations established from seeds obtained from two Polish mixed-oak selected seed stands located in Legnica (51 $\left.12^{\circ} \mathrm{N}, 16^{\circ} 10^{\prime} \mathrm{E}\right)$ and in Jamy (53 $34^{\prime} \mathrm{N}$, $\left.18^{\circ} 55^{\prime} \mathrm{E}\right)$. Species composition of both stands is given in Table I. Although the origin of adult stands is unknown, in both stands any
Table I. Species composition of selected seed stands.

\begin{tabular}{lccccc}
\hline Site & Age & $\begin{array}{c}\text { Number } \\
\text { of individuals }\end{array}$ & $\begin{array}{c}\text { Pedunculate } \\
\text { oak }(\%)\end{array}$ & $\begin{array}{c}\text { Sessile } \\
\text { oak }(\%)\end{array}$ & $\begin{array}{c}\text { Putative hybrids } \\
(\%)\end{array}$ \\
\hline Jamy & 120 & 456 & 57 & 41.2 & 1.8 \\
Legnica & 150 & 1452 & 53.5 & 44.4 & 2.1 \\
\hline
\end{tabular}

silvicultural treatments which could influence on species composition were not carried out since the stands have got selected seed stand status.

Taxonomical status of all individuals from adult stands was assessed according to the following characteristics: (1) length of petiole: up to $5 \mathrm{~mm}$ for pedunculate oak and $>5 \mathrm{~mm}$ for sessile oak; (2) shape of lamina: inversely oval and deeply lobed for pedunculate oak and oval but less deeply lobed for sessile oak; (3) leaf base: wedge-shaped for sessile oak and cordate or auriculate for pedunculate oak; (4) sinus depth: up to one-third of lamina width for sessile oak and deeper for pedunculate oak; and (5) presence of intercalary veins (whole lamina): up to 3 veins for pedunculate oak, and less for sessile oak. Although none of these features is diagnostic, leaf morphology has been the most important discriminator for oak taxa [7]. Individuals with intermediate or mosaic phenotypes were classified as hybrids.

Five artificial progeny plantations were chosen from Jamy, established in five different years, and two plantations established in the same year were chosen from Legnica. The dates of progeny plantation establishing are strictly related with the mast year, since oak's mast year is not noted every year. As far as we know, in every mast year complete harvest of acorns from the total area of adult stands was made, without any species-specific acorn selection. Natural regeneration from both stands was also included. The seedlings from natural regeneration were collected under the canopy of maternal stands and were about 10 to 20 years old. In natural regeneration we noted seedlings 10 to 20 years old and very young, 1 or 2 years old. Since the morphological analysis can not be used for very young oak seedlings due to high phenotypic plasticity of species and probability of misclassification, we decided to include older seedlings for our natural regeneration morphological analysis.

In July and August 2004, material for the studies was collected. In each progeny plantation and natural regeneration, 100 individual trees were sampled at random. From 3 to 10 fully expanded leaves were sampled from individual trees from plantations and 10 leaves per tree in natural regenerations. The taxonomical status of all individuals sampled both in progeny plantation and in natural regeneration was assessed using the same methodology as in case of individuals from adult stands. Any silvicultural treatments were not made in any of progeny plantations or in natural regeneration what could affect on species composition.

The statistical significance of differences in species composition between adult populations and progeny populations was tested with ChiSquare test. Statistical analysis were conducted with using Jump v. 5.1.

\section{RESULTS}

The most striking results were the notable differences in species composition between seed stands and their progeny plantations and natural regeneration. The species composition 
Table II. Species composition of progeny plantations (100 individuals/plantation).

\begin{tabular}{lcccc}
\hline Site & $\begin{array}{c}\text { Establishment } \\
\text { year }\end{array}$ & $\begin{array}{c}\text { Pedunculate } \\
\text { oak }(\%)\end{array}$ & $\begin{array}{c}\text { Sessile } \\
\text { oak }(\%)\end{array}$ & $\begin{array}{c}\text { Putative } \\
\text { hybrids }(\%)\end{array}$ \\
\hline Jamy & 1987 & 98 & 2 & 0 \\
& 1992 & 95 & 4 & 1 \\
& 1996 & 96 & 4 & 0 \\
& 1998 & 97 & 3 & 0 \\
Average & 2003 & 97 & 3 & 0 \\
Legnica & 1985 & 89 & 7 & 4 \\
& 1985 & 90 & 9 & 1 \\
Average & & $\mathbf{8 9 . 5}( \pm \mathbf{0 . 7 1})$ & $\mathbf{8 ( \pm \mathbf { 1 . 4 1 } )}$ & $\mathbf{2 . 5}( \pm \mathbf{2 . 1 2})$ \\
\hline
\end{tabular}

Table III. Species composition of natural regeneration (100 individuals/population).

\begin{tabular}{lcccc}
\hline Site & Age & $\begin{array}{c}\text { Pedunculate oak } \\
(\%)\end{array}$ & $\begin{array}{c}\text { Sessile oak } \\
(\%)\end{array}$ & $\begin{array}{c}\text { Putative hybrids } \\
(\%)\end{array}$ \\
\hline Jamy & $10-15$ & 16 & 76 & 8 \\
Legnica & $15-20$ & 1 & 98 & 1 \\
\hline
\end{tabular}

of all studied progeny populations and natural regenerations is given in Tables II and III. Despite almost equal proportions of both species in seed stands (Tab. I), $Q$. robur was the dominant species in progeny plantations regardless of year of establishment or stand. In five plantations from Jamy, $Q$. robur was $96.6 \%$, and in Legnica, it was $89.5 \%$ on average; however, $Q$. petrea was only $3.2 \%$ in Jamy and $8 \%$ in Legnica. $Q$. petrea dominated in natural regeneration in both stands (76\% Jamy, 98\% Legnica) and $Q$. robur was in the minority in both (16\% Jamy, $1 \%$ Legnica).

Morphologically intermediate or mosaic individuals were noted in different amounts in analyzed populations (Tabs. II and III). Among artificial populations, the highest number of putative hybrid individuals was observed in Legnica (2.5\% on average) and the lowest in Jamy ( $0.2 \%$ on average). In natural regeneration from Jamy, up to $8 \%$ of individuals were scored as putative hybrids; in Legnica, this frequency was $1 \%$.

All noted differences in species composition between adult stands and their progeny populations (natural regenerations and progeny plantations) were statistically significant at $p<0.001$.

\section{DISCUSSION}

If we consider only the species composition of maternal selected seed stands, the results were unexpected. It should be emphasized that direct selection of acorns according to species was not performed in any of the studied seed stands. In every mast year, all seeds in both stands were collected, sowed in the nursery, and subsequently used for establishing progeny plantations. The question that arises is what may have caused the disproportion in species composition between selected seed stands, progeny plantations, and natural regeneration?

The ecological amplitude of $Q$. petrea goes beyond that of $Q$. robur. Ecophysiological differences account for the advantage of sessile oak in mixed stands. Because it is a latesuccession species, it tolerates denser and more shaded conditions. By contrast, pioneer pedunculate oak requires open spaces to regenerate. Also the viability of $Q$. robur acorns rapidly decreases if water is lost, and $Q$. petrea seeds are more resistant to desiccation. These are the main reasons explaining the easier natural regeneration of sessile oak under the adult trees canopy, that we have identified in our studies.

The most striking result concerns species composition of progeny populations. In every progeny population, $Q$. robur is the dominant species and $Q$. petrea is in the minority. Several explanations are possible. First, indirect selection of acorns cannot be excluded. Acorns of $Q$. petrea germinate very quickly (earlier than $Q$. robur) and often are viviparous $[27,30]$. This characteristic may have resulted in the avoidance of germinating seeds during collection since collected seeds were also intended for storing (Suszka, personal communication). Moreover, vivipary observed in sessile oak may increase fungal pathogen infections, in particular those caused by Ciboria batschiana. Acorns of sessile oak are much more prone to this pathogen infection because of damage in seed cover appearing during rapid germination or germination on the mother tree. Infections caused by $C$. batschiana may eliminate a vast amount of collected seeds [26]. Second, seeds of pedunculate oak are bigger, which simply results in their being preferentially collected. Selection in the nursery may also have a strong influence on the apparent disproportion in species composition in progeny plantations. Before being planted into the progeny plantation, seedlings are classified and selected with respect to overall health and size, and only the best are chosen. Because juvenile growth of pedunculate oak is faster than that of sessile oak [11], the possibility of the choice of pedunculate oak seedlings for planting increases.

It also seems likely that a different pattern of fruiting between species could contribute to the observed disproportion in species representation in progeny plantations. Seed production that is synchronous but variable between years within a population is a well-known phenomenon in long-lived plant species and is also reported among oak species. Moreover, interannual variation in acorn production among individual trees appears to be the rule among oak species. Unfortunately, studies concerning differences in fruiting patterns between pedunculate and sessile oak are scarce. Information gained from 10 Forest Districts supports the existence of such differences. Good acorn crops in pedunculate oak are noted every 4-8 years; on the other hand, sessile oak can fruit more frequently (almost every year) but is less abundant than the other species. In addition, irregular seed production is observed at the edge of the species range for $Q$. petrea in Poland [29].

Another explanation of the situation observed in artificial and natural progeny populations takes into account sex ratio and the model of invasion through pollen in oaks [22]. Pollen flow is much more effective than seed flow in oaks. Asymmetrical hybridization from $Q$. petrea to $Q$. robur is thought to 
act as a dispersal mechanism facilitating colonization of pedunculate oak stands by sessile oak. In fact, it has been recently confirmed that hybridization can effectively influence displacement of native species by invasive species [10].

Oaks are monoecious and individual trees may show a biased reproductive investment favoring one of the sexes [5]. Such a trend in $Q$. petrea in a particular context could be regarded as part of its strategy in progressively replacing $Q$. robur in successional forest development. Differences in sex allocation in dioecious and monoecious plant species are reported and depend on many different factors [8, 9, 13, 18]. Monoecious, wind-pollinated plant species are expected to exhibit a higher relative investment in male sex because the threat of losing large amounts of pollen during pollination is high. Increasing production of pollen is a strategy to improve reproductive success. In the case of the sessile oak, it could have another meaning. The mechanism of seed dispersion is much more effective in $Q$. robur than in $Q$. petrea mainly because of preferential collection by jays [4]. Therefore, enhanced male investment in sessile oak could be a compensation for lesseffective seed flow, which would enable and reinforce effective colonization. However, verification of this hypothesis requires detailed studies of the flowering and fruiting biology of both species.

Considering the lack of any species-specific traits, it is still difficult to draw conclusions about the real extent of the natural hybridization. Our investigation based on morphological analysis indicates a varied, low extent of hybridization in mixed stands, consistent with other studies employing morphological analysis [1,7]. Controlled pollination studies carried out by Steinhoff [25] indicated asymmetry in interspecific gene flow. Surveys of mating systems reported asymmetrical compatibility between $Q$. robur and $Q$. petrea genes in natural stands. The genetic contribution of $Q$. petrea to the $Q$. robur progenies was confirmed and varies from $17 \%$ to $48 \%$ [2]. Asymmetrical hybridization could be a subsequent step of the sessile oak colonization strategy. Because the interspecific pollen flow is larger than seed flow, it results in the dispersal of the pollen parent, which is sessile oak. Asymmetrical hybridization and repeated backcrossing with the pollen parent can contribute to progressive replacement of $Q$. robur by $Q$. petrea.

Some other factors should be taken into account when considering hybridization. Hybridization is a dynamic process and thus can be influenced by ecological factors, which locally can reinforce or inhibit intermating between species (synchronization in flowering phenology, part of distribution range, edaphic and weather conditions, etc.). What is more, it cannot be excluded that hybridization success has an individual context and can depend on the genetic constitution of particular intermating individuals. In fact, differences in the extent of hybridization among vegetative seasons were found in our study.

In conclusion, the contrasting species compositions between maternal populations, their progeny populations, and natural regeneration may have originated in the procedure for collecting acorns and in the establishing of progeny plantations. It may also have resulted from the unique asymmetry of seed and pollen dispersal in $Q$. petrea. Asymmetry accompanied by one-way hybridization enables and facilitates col- onization into $Q$. robur stands. Increased male investment in sessile oak would be an important part of the colonization strategy. However, competition between these two species is expected to take place under specific conditions that are primarily beyond the optimal for pedunculate oak; ecophysiological differences between the species are strongly pronounced. To answer the questions related to the evolution and functioning of such a model of colonization and competition between species, detailed studies are needed. The evaluation of the extent of hybridization and hybrid fitness especially would help our understanding of the role of observed gene exchange between sessile and pedunculate oak and between other species in general. In addition, as long as the extent of hybridization and its impact on progeny fitness cannot be estimated, in our opinion there is no need for converting mixed-oak stands into one-species stands, which would involve damage to such often-valuable stands.

However, some important factors need to be taken under consideration when the existence of such mixed oak selected stands is discussed. It needs to be stressed, that both species are of economical importance. As we have presented in our study, in such mixed oak stands, practically only pedunculate oak is planted, sessile oak is omitted. This is a result of not including into the seeds harvest protocols the ecophysiological differences between species. The only reasonable way is speciesspecific acorns selection in such mixed selected stands, what may ensure the planting needed species.

Acknowledgements: We thank Prof. Adam Boratynski and Dr. Krystyna Boratynska for taxonomical assistance and helpful comments on earlier drafts of this paper. We are also very grateful to Maria Ratajczak and Anna Jasinska for technical assistance. This work was supported by a research grant from the State Forests in Poland.

\section{REFERENCES}

[1] Aas G., Taxonomical impact of morphological variation in Quercus robur and $Q$. petrea: a contribution to the hybrid controversy, Ann. Sci. For. 50 (Suppl. 1) (1993) 107-113.

[2] Bacilieri R., Ducousso A., Petit R.J., Kremer A., Mating system and asymmetric hybridization in a mixed stand of European oaks, Evolution 50 (1996) 900-908.

[3] Boratyñska K., Dąb bezszypułkowy (Quercus petrea (Mat.) Lieb.) w północno-wschodniej Polsce, Arbor. Kórnickie 24 (1979) 69-86.

[4] Bossema I., Jays and oaks: eco-ethological study of a symbiosis, Behavior 70 (1979) 1-117.

[5] Ducousso A., Michaund H., Lumaret R., Reproduction and gene flow in the genus Quercus L., Ann. Sci. For. 50 (Suppl. 1) (1993) 91-106.

[6] Dumolin-Lapegue S., Kremer A., Petit R.J., Are chloroplast and mitochondrial DNA variation species independent in oaks? Evolution 53 (1999) 1406-1413.

[7] Dupouey J.L., Badeau V., Morphological variability of oaks (Quercus robur L., Quercus petrea (Matt.) Lieb., Quercus pubescens Willd.) in northeastern France: preliminary results, Ann. Sci. For. 50 (Suppl. 1) (1993) 35-40.

[8] Goldman D.A., Willson M.F., Sex allocation in functionally hermaphroditic plants: a review and critique, Bot. Rev. 52 (1989) 157- 194. 
[9] Guitian J., Medrano M., Oti J.E., Variation in floral sex allocation in Polygonatum odoratum (Liliaceae), Ann. Bot. 94 (2004) 433-440.

[10] Huxel G.R., Rapid displacement of native species by invasive species: effect of hybridization, Biol. Conserv. 89 (1999) 143-152.

[11] Krahl-Urban J., Die Eichen, Hamburg, Paul Parey 1959.

[12] Kremer A., Dupouey J.L., Deans J.D., Cottrell J., Csaikl U., Finkeldey R., Espinel S., Jensen J., Kleinschmit J., van Dam B., Ducousso A., Forrest I., de Heredia U.L., Lowe A.J., Tutkova M., Munro R.C., Steinhoff S., Badeau V., Leaf morphological differentiation between Quercus robur and Quercus petrea is stable across western European mixed oak stands, Ann. For. Sci. 59 (2002) 777-787.

[13] Le Corff J., Ågren J., Schemske D.W., Floral display, pollinator discrimination and female reproductive success in two monoecious Begonia species, Ecology 79 (1998) 1610-1619.

[14] MacPherson A.B., Mori S.R., Wood D.L., Storer A.J., Svihra P., Kelly M.N., Standiford R.B., Sudden oak death in California: disease progression in oaks and tanoaks, For. Ecol. Manage. 213 (2005) 71-89.

[15] Matras J., Rejestr bazy nasiennej w Polsce, Instytut Badawczy Leśnictwa, Warszawa, 1996.

[16] Matras J., Burzyñski G., Czart J., Fonder W., Korczyk A., Puchniarski T., Tomczyk A., Załęski A., The programme for the conservation of forest genetic resources and the breeding of forest tree species in Poland in the years 1991-2010, Centrum Informacyjne Lasów Pañstwowych, Warszawa, 2000.

[17] Mariette S., Cottrell J., Csaikl U.M., Goikoechea P., König A., Lowe A.J., van Dam B.C., Barreneche T., Bodènés C., Streiff R., Burg K., Groppe K., Munro R.C., Tabbener H., Kremer A., Comparison of levels of genetic diversity detected with AFLP and Microsatellite markers within and among mixed $Q$. petrea (Matt.) Lieb. and Q. robur L. stands, Silvae Genet. 51 (2002) 72-79.

[18] Obesco J.R., The costs of reproduction in plants, New Phytol. 155 (2002) 321-348.

[19] Oleksyn J., PrzybyłK., Oak decline in the Soviet Union. Scale and hypotheses, Eur. J. For. Pathol. 17 (1987) 321-336.

[20] Petit R.J., Kremer A., Wagner D.B., Geographic structure of chloroplast DNA polymorphisms in European oaks, Theor. Appl. Genet. 87 (1993) 122-128.
[21] Petit R.J., Brewer S., Bordács S., Burg K., Cheddedi R., Coart E., Cottrell J., Csaikl U.M., van Dam B., Deans J.D., Espinel S., Fineschi S., Finkeldey R., Glaz I., Goicoechea P.G., Jensen J.S., König A.O., Lowe A.J., Flemming Madsen S., Mátyás G., Munro R.C., Popescu F., Slade D., Tabbener H., de Vries S.G.M., Ziegenhagen B., Beaulieu J.L., Kremer A., Identification of refugia and post-glacial colonization routes of European white oaks based on chloroplast DNA and fossil pollen evidence, For. Ecol. Manage. 156 (2002) 49-74.

[22] Petit R.J., Bodènés C., Ducousso A., Roussel G., Kremer A., Hybridization as a mechanism of invasion in oaks, New Phytol. 161 (2003) 151-164

[23] Rushton B.S., Natural hybridization within the genus Quercus L., Ann. Sci. For. 50 (Suppl. 1) (1993) 73-90.

[24] Steinhoff S., Results of species hybridization with Quercus robur L. and Quercus petrea (Matt) Lieb., Ann. Sci. For. 50 (Suppl. 1) (1993) 137-143.

[25] Steinhoff S., Controlled crosses between pedunculate and sessile oak: results and conclusion, Allg. Forst-u. J. 169 (1998) 163-168.

[26] Siwecki R., Przyczyny zamierania żołędzi w sezonie jesiennowiosennym 1992/1993 w kilku nadleśnictwach północnej Polski, Sylwan 2 (1994) 49-54.

[27] Suszka B., Muller C., Bonnet-Masimbert M., Nasiona leIJnych drzew liściastych, Od zbioru do siewu, Wydawnictwo Naukowe PWN, Warszawa-Poznañ, 1994.

[28] Tutkova-van Loo M., Burg K., Chloroplast haplotype diversity of white oak species in Slovakia and the Czech Republic: results from PCR-RFLP analysis and phylogeographic interpretations, For. Genet. 10 (2004) 125-137.

[29] Tomanek J., Botanika Leśna. Pañstwowe Wydawnictwa Rolnicze i Leśne, Warszawa, 1994.

[30] Tyszkiewicz S., Nasiennictwo leśne, Instytut Badawczy Leśnictwa, Warszawa, 1949

[31] Chodnik T., Zasady Hodowli Lasu, Kryteria rozpoznania przyrodniczych warunków produkcji leśnej, Pañstwowe Wydawnictwo Rolnicze i Leśne, Warszawa, 1980.

[32] Zaręba R., O potrzebie zróżnicowania obydwu gatunków naszych dębów w gospodarce leśnej, Las Polski 8 (1962) 16-17. 